\title{
Effectiveness comparison of guided discovery and semi-guided discovery learning models toward the fact-finding skill on plantae material
}

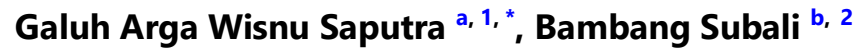 \\ ${ }^{a}$ Biology Education, Post Graduate Programme, Yogyakarta State University, Yogyakarta, Indonesia \\ ${ }^{\mathrm{b}}$ Department of Biology Education, Graduate Programme, Yogyakarta State University, Yogyakarta, \\ Indonesia \\ 1'galuharga16@gmail.com, ${ }^{2}$ bambangsubali@uny.ac.id \\ * Corresponding author
}

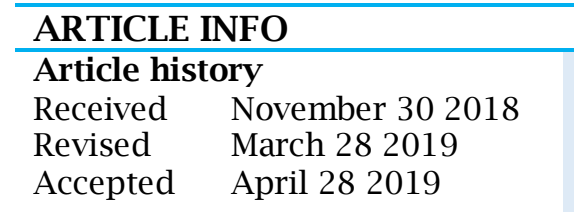

\section{Keyword:}

Guided discovery

Semi-guided discovery

Fact-finding skill.

\begin{abstract}
The purpose of this research was to discover the differences in learning outcomes of fact-finding in the implementation of guided discovery and semi-guided discovery learning models on plantae material at X grade of National 1 High School of Jetis Bantul. This research was conducted on experimental group class that carried out learning with guided discovery and the control class with semi-guided discovery learning. The design of this research was the randomized pretest-posttest control group design. The quantitative data were the learning outcomes of cognitive domain which obtained from the values of pretest and posttest, that analyzed through T-test at 5\% significance level. Based on the test, it was obtained $p=0.000(p<0.05)$ so there was a significant difference between the guided discovery and semi-guided discovery learning model toward the fact-finding skill on the learning outcomes of student. The fact-finding skills of guided discovery was higher than semi-guided discovery learning with pretest average of control class students (41.53) and the experimental class (41.97), while the postest average of control class (69.75) and experimental class (80.66). The learning through the implementation of guided discovery learning model was more effective than semi-guided discovery learning model toward fact-finding skill.
\end{abstract}

This is an open access article under the CC-BY-SA license.

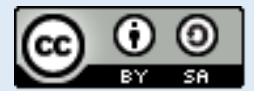

\section{Introduction}

Learning is an interaction process between teachers and students as well as between the students and the environment, therefore, a change into a better behavior could occur. This interaction can be determined as the teaching and learning process in which the teaching and learning process is an activity which occurs between teachers and students as well as the communication between teachers and students in an educative atmosphere to achieve the learning purposes. According to Jihad and Haris (2012), "Learning outcomes are the actual change of students behaviors after the teaching and learning process is performed in accordance with the learning purposes". 
The rapid transformation in the present global era can affect the way of live of individuals and the requirement for learning skills that have to be mastered to stay updated with the era (Beers, Beers, \& Smith, 2009). The development occurs at the present demands the students to conceive the learning skills which include critical-thinking, problem-solving, the ability to communicate, collaborate, being creative, science literacy and having global awareness which integrated in the learning process (Alderman \& MacDonald, 2015). Learning skills are highly beneficial to equip the students in facing the developing global era. Alderman and MacDonald (2015) stated that all students need proper education, thus, they could develop complexly and capable of following the continuous changes in the world. Learning skills can be developed by students through their activeness during the learning process.

The activeness of students during the learning process can provide stimulus and developing the talents owned by the students as well as supporting them in solving problems of daily lives. The active students in class can support the learning progress that is running, improving the interaction occurs between teachers and student or between students. Mulyasa (2002) stated that the activeness of students during the learning process indicates that successful and quality learning process. Yamin (2007) explained that teachers plan a learning system in orderly manner, therefore, it could enhance the activeness of students during the learning process. Gasong (2018) explained that the activeness of students during the learning process is the factor that affects the learning outcomes. Nasution (2000) added that teachers in the learning process encourage the students to think actively by creating the learning condition which demands to be active in delivering their arguments, having solution in solving the problems, thus, they could give better learning outcomes.

One example that occurs in National 1 High School of Jetis Bantul. The results of the observations indicate that student learning activities in the class are less varied. The teacher only uses lecture and discussion methods while teaching, because when the teacher uses some varied learning the results are not in line with her expectations. This causes students to feel bored in learning. Usually students prefer to copy material from their books, rather than watching directly. This makes them less understanding when faced with a problem that must be resolved. One alternative to overcome the problems that occur in National 1 High School of Jetis Bantul is by using guided discovery learning model and semi guided discovery learning model which is a discovery learning model conducted with guidance from the teacher, this is because high school students 1 Jetis Bantul still needs teacher guidance before finding the new concept.

The discovery learning is confronting the students on various situations, questions, and assignments that make them to active in finding facts and concepts or materials for themselves (Wilke \& Straits, 2001). The stages in Guided Discovery Learning include gathering and classifying information, formulating problems, formulating hypothesis, creating prediction, and translating outputs of the experiment, then, the students conclude the knowledge from the provided information (Swaak, De Jong, \& Van Joolingen, 2004). According to Wilke and Straits (2001), the involvement of students during the learning process produces more different approaches in understanding content, improves the activity of students during the completion of assignments and helps students to construct knowledge as well as involves broader processing of ideas to solve problems, Discovery Learning encourages students to learn more actively by establishing concepts and principles, students also encouraged by teachers to acquire experiences and connect both of the elements to discover the principles for themselves.

The definition of Guided Discovery Learning is an approach in which teachers provide the students with examples regarding a specific topic and guide them to understand the topic (Eggen \& Kauchak, 2012). Working independently to seek for problem solution and the knowledge that comes within it will provide a truly meaningful knowledge. According to Sapriati (2009), there are two types of discovery learning, namely free discovery model and guided discovery model. Free discovery model is the discovery learning model with no guidance or direction. While guided discovery learning is the learning model which requires the role of teachers as the facilitator in the learning process. The guided discovery learning is being more implemented compared to free discovery 
learning because the teachers will give direction to students in guided discovery learning. Thus, the students will be more directed in the effort of achieving predetermined purposes.

\section{Method}

This research was conducted in National 1 High School of Jetis Bantul in February 2018. The population in this research was the entire X class of National 1 High School of Jetis Bantul. The sample in this research was X3 class as the control group and $\mathrm{X} 4$ as the experimental group derived through a purposive sampling technique. The design of this research was the randomized pretest-posttest control group design. Thus, the design structure of this research was presented in Table 1.

Table 1. Research Design

\begin{tabular}{cccc}
\hline Group & $\begin{array}{c}\text { Initial } \\
\text { Skill }\end{array}$ & Treatment & $\begin{array}{c}\text { Final } \\
\text { skill }\end{array}$ \\
\hline $\mathrm{I}$ & $\mathrm{O}_{1}$ & $\mathrm{X}_{1}$ & $\mathrm{P}_{1}$ \\
II & $\mathrm{O}_{2}$ & $\mathrm{X}_{2}$ & $\mathrm{P}_{2}$ \\
\hline
\end{tabular}

$\mathrm{I}=$ Control Class; $\mathrm{II}=$ Experimental Class;

$\mathrm{O}_{1} \& \mathrm{O}_{2}=$ Pretest;

$\mathrm{X} 1=$ Semi-Guided Discovery Learning Model;

X2 = Guided Discovery Learning;

$\mathrm{P}_{1} \& \mathrm{P}_{2}=$ Posttest.

The data were collected through the test technique. The test technique is performed to measure the fact-finding skill. The test instrument used is a validated essay question instrument. The collected data are analyzed descriptively and inferentially. Descriptive analysis to find the maximum, minimum, average student score, standard deviation, range, and variant. Inferential analysis was conducted to know the difference between guided discovery and semi-guided discovery learning model toward student fact-finding skills.

\section{Results and Discussion}

The data hypothesis test used in this research was the difference test through the application of the Independent Sample Ttest. Independent Sample T-test was performed to acquire a decision about whether the hypothesis of the research. The result of the Independent sample t-test showed in which the testing is as follows in Table 2.
Table 2. The decision hypothesis test

\begin{tabular}{lccl}
\hline Type of Data & $\begin{array}{c}\text { Sig (2- } \\
\text { tailed) }\end{array}$ & $\boldsymbol{\alpha}$ & Decision \\
\hline Experimental & 0.000 & 0.05 & $\begin{array}{l}\text { H0 is } \\
\text { rejected } \\
\text { and Control }\end{array}$ \\
Classes & & $\begin{array}{l}\text { (significant } \\
\text { difference } \\
\text { occurs) }\end{array}$ \\
\hline
\end{tabular}

According to Table 2, the result of the hypothesis test has indicated that there is a significant difference between guided discovery and semi-guided discovery learning models toward fact-finding skills.

The research result based on the explanation above has explained the various data acquired in this research. Based on the available data, it shows that the hypothesis that the researcher built is proven. The hypothesis in this research was, "Is the application of guided discovery learning model better than the application of semi-guided discovery learning toward fact-finding."

This discussion will answer the reason for the comparison of a theory that constructs the proven hypothesis. This discussion will answer the effectiveness of guided discovery learning or semi-guided discovery learning models in measuring the ability/skill in finding facts.

The effectiveness analysis of semi-guided and guided discovery learning models toward fact-finding skill

The test results through the application of the T-test have indicated the values in which the probability was 0.000 . This condition shows that if $\mathrm{p}<0.05$, thus, both values have a significant difference. After performing the processing of data analysis in a descriptive manner through the application of SPSS software, the class given with test before the treatment on experimental group has the highest result value (53), while the lowest score was 33 with 41.97 of average value and 4.961 standard of deviation. While on the control group, the highest score which acquired was 53 , and the lowest score was 28 with 41.53 of average value and 6.965 standard of deviation. Then, the class given with the test after the treatment of learning on control group has acquired the highest value (89) while the lowest score was 67 with 80.66 of average and 5.522 standard of deviation. On the control group, the highest score acquired was 78,61 as the lowest score, 69.75 of average score, and 4.738 standard of deviation. 
The differences occurred because in the learning process through the implementation of guided discovery learning model on experimental class; the teachers provide more guidance to students, while the learning on control class through the implementation of semi-guided discovery learning; the teachers give different treatment during the guidance when the learning process is running.

Guided discovery model learning adheres to the constructivism view that emphasizes understanding the concept of learning through the active role of students (Hamalik, 2003). In line with this, Lazonder and Harmsen (2016) stated that inquiry based learning can be more effective than other, more expository instructional approaches or guidance as long as students are supported adequately. Minimally guided instruction is less effective and less efficient than instructional approaches that place a strong emphasis on guidance of the student learning process (Kirschner, Sweller, \& Clark, 2006). It can be concluded that guided inquiry strategy is effective toward student's cognitive result (Abdisa \& Getinet, 2012; Fitri, Anggraito, \& Alimah, 2018).

The comparison of fact-finding skill which given with treatment of semi guided and guided discovery learning models.

After the measurement of data processing with hypothesis test was conducted through SPSS by using t-test; $\alpha=$ 0.05 has been acquired. This result has fulfilled the requirement for data testing of hypothesis test in which the data of prerequisite processing test have to be normal and homogenous. The normality test was conducted to determine whether the data used are having normal distribution on fact-finding skill while the next test namely homogeneity test was conducted to determine whether the data used have homogenous variation from the used sample population.

The test results by using Kolmogorovsmirnov test in this research which conducted in the Pretest experimental class have shown 0.057 value of $p$, this result has shown that $p>0.05$. It means that the data for experimental group were distributed normally. While the data analysis for Posttest experimental group has resulted in $\mathrm{p}=0.622$. It means that the data for experimental group were normal and both classes were having the same normal results.
Discussing in further, the homogeneity test was conducted by seeing the test results of Pretest in which the Lavene test has indicated 0.070 value of fact-finding skill. The probability value was higher than 0.05 , therefore, it can be determined that Ho was rejected or unaccepted. Thus, the next step was taking a conclusion that the data of fact-finding value have homogenous variance. While on the Posttest, the Lavene test has indicated that the result of factfinding value was 0.431 . The probability value was higher than 0.05 , therefore, it can be determined that Ho was rejected or unaccepted. Thus, the next step was taking a conclusion in which the data of factfinding value have homogenous variance.

The interest of students toward guided discovery learning was caused by more enthusiasm that can be shown by them, making them to have more pleasure in following the lesson in class because when the students are happy with the lesson in class; they are expected to have satisfying final grades (Kertamuda, 2008). Kertamuda then added that in the time students are involved directly during the learning process, this condition will encourage them to be more creative and critical in solving the problems faced by them in which this situation will make them to be happy and prevent boredom during the learning process in class.

Guided discovery model is able to improve the understanding concept and critical thinking ability of students (Widhiyantoro, Indrowati, \& Probosari, 2012; Yuliani \& Saragih, 2015). The use of guided discovery and think-pair-share strategies had great potential for improving achievement in chemistry and science learning generally (Bamiro, 2015). While experts often thrive without much guidance, nearly everyone else thrives when provided with full, explicit instructional guidance (Clark, Kirschner, \& Sweller, 2012). It was suggested that teachers can use guided discovery learning model by presenting problems related to daily life as an alternative student learning (Yuliani \& Saragih, 2015). This is reinforced by Abdisa and Getinet (2012), that teachers in the zone should implement guided discovery with sufficient guidance to help students create, integrate, and generalize knowledge through constructivist problem solving by providing them with materials available in lab or locally prepared teaching materials. 
Some stages in the guided discovery learning model include the orientation stage with a purpose that in the time the students faced with the problems; they would be ready. The conducted research was brought in the genuine preparation of moss in the first meeting, the second meeting used ferns, and the third meeting used the seed plants, each meeting used different preparation, thus, it motivated the students to ask question. During learning process teachers must be able to devise appropriate learning model and media in order to create encouraging atmosphere and to motivate students to actively participate in learning process. Learning model and media in use should be able to help teachers in building good interaction with the students so that they are able to comprehend learning materials and be creative in solving a problem (Gunawan, Sahidu, Harjono, \& Suranti, 2017). Students to learn very well and create interest in science it must be taught with good instructional materials (Nchunga \& Kira, 2016).

The next was the stage of hypothesis drawing or temporary assumption which has been discovered by students. The temporary assumption or temporary answer which has been formulated by the students was based on their initial knowledge that acquired from the learnt material. The researcher formulated the stage of initial knowledge of students by inviting them to find the preparation around their living environment. Then, high curiosity will occur that stimulates inquisitiveness. The application of virtual reality to education is potential. Accordingly, virtual reality could assist students in the concept creation, the feasibility and completeness of originate, rare, and feasible novelty, as well as the performance on delicate and beautiful value multi-purpose (Hu, Wu, \& Shieh, 2016).

The feeling that comes on the next stage was able to stimulate the students to prove the formulated hypothesis through group discussion in finding facts and establishing concept by considering the procedures to acquire data. The activity that stimulates the students to become curious of learning new things will make them discovering a fact from the process undergone by them. Beside that, implementing effective instructional techniques like collaborative learning has the potential to help ensure students are achieving the outcomes including critical thinking that are championed by colleges and universities throughout the nation (Loes \& Pascarella, 2017).

Then, the study of Mirasi, Osodo, and Kibirige (2013) explained the similar condition in which the problems formulated by teachers will cause the students to perform activities that able to stimulate them to conduct experiment and then performing observation which will generate the answer regarding what they being conducted. This kind of learning process is expected to be able of training students to become independent and proving whether the conducted activities have been in accordance with the answer of the hypothesis constructed by them.

The next activities were data collecting and data processing that included in the hypothesis testing phase. The next stage was testing hypothesis or testing assumption while students will be guided to look for data from observations of preparations directly and then determine what can be used as a reference to obtain additional information. The control class was less coordinated in collecting data and processing data because of the lack of guidance from the teachers, in contrast to the experimental class which guided by the teachers in data collection and data processing in which it became directed and acquired more information. Then in line with the results above, the study of Honomichl and Chen (2012) stated that when conducting experiment, the activities that are used to solve problems will increase the insight of students about the ability to find facts.

The next stage was the regulation which functioned to communicate the discussion results. The students communicate the results of group discussion in front of the class regarding moss plant on the first meeting, the discussion regarding ferns on the second meeting, and the seed plants on the third meeting, in that order, the teachers examine the skill of students in implementing concept through the procedures constructed from facts gathered by them. The next stage was the last namely concluding the conducted activities. At this stage, teachers contribute as the additional informant of the results of the experiment conducted by students for the activities done by them could provide benefits in the discovery of facts of the problems discussed in groups. 
The data results of the conducted research were consistent with the study of Kypuros, Tarawneh, Vasquez, Knecht, and Wrinkle (2012) which explained that during the direct involvement of students in learning process; the fact-finding skill of students can be improved. The process of finding this fact is very important because to achieve a higher objective or category, one must first master cognitive processes at a lower category. In other words, before comprehension, application, or analysis can take place, a student must first acquire knowledge (Agarwal, 2019).

According to the study of Aunurrahman (2009), it has been explained that the learning process in school will be successful as well due to the teachers who conceive skill or competency in educating and formulating the learning instrument, therefore, that element makes the students to be more active. According to the formulated design; the students were also involved directly to make them more intrigued by what presented by the teachers that make them more active. In line with Furtak et al. (2016), these practices have been linked to positive learning outcomes for students, designing and enacting.Based on the presentation of data above regarding the effectiveness of two learning models namely guided discovery and semi-guided discovery learning toward fact-finding skill, it can be defined that the application of guided discovery learning during the learning process has provided more positive results toward the fact-finding skill.

\section{Conclusion}

From the results of this research, there was a significant difference between the guided discovery and semi-guided discovery learning model toward the fact-finding skill on the learning outcomes of the student. The research results have indicated that learning through the implementation of a guided discovery learning model was more effective than a semi-guided discovery learning model toward fact-finding skills.

\section{References}

Abdisa, G., \& Getinet, T. (2012). The effect of guided discovery on students' physics achievement. LatinAmerican Journal of Physics Education, 6(4), 530-537. Retrieved from http://www.lajpe.org/dec2012
/4_LAJPE_715_Tesfaye_Getinet_pre print_corr_f.pdf

Agarwal, P. K. (2019). Retrieval practice \&amp; Bloom's taxonomy: Do students need fact knowledge before higher order learning? Journal of Educational Psychology, 111(2), 189209. https://doi.org/10.1037/edu00 00282

Alderman, M. K., \& MacDonald, S. (2015). A self-regulatory approach to classroom management: Empowering students and teachers. Kappa Delta Pi Record, 51(2), 52-56. https://doi.org/10.1080/00228958. 2015.1023145

Aunurrahman, A. (2009). Belajar dan pembelajaran. Bandung: Alfabeta.

Bamiro, A. O. (2015). Effects of guided discovery and think-pair-share strategies on secondary school students' achievement in chemistry. SAGE Open, 5(1), 1-7. https://doi. org/10.1177/2158244014564754

Beers, C. S., Beers, J. W., \& Smith, J. O. (2009). A principal's guide to literacy instruction. New York: Guilford Press.

Clark, R. E., Kirschner, P. A., \& Sweller, J. (2012). Putting students on the path to learning: The case for fully guided instruction. American Educator, 36(1), 6-11. Retrieved from https:// eric.ed.gov/?id=EJ971752

Eggen, P. D., \& Kauchak, D. P. (2012). Strategies and models for teachers: Teaching content and thinking skills. London: Pearson.

Fitri, F. A., Anggraito, Y. U., \& Alimah, S. (2018). The effectiveness of guided inquiry strategy on students' collaborative skill. Journal of Biology Education, 7(2), 144-150. https:// doi.org/10.15294/jbe.v7i2.24278

Furtak, E. M., Kiemer, K., Circi, R. K., Swanson, R., de León, V., Morrison, D., \& Heredia, S. C. (2016). Teachers' formative assessment abilities and their relationship to student learning: findings from a four-year intervention study. Instructional Science, 44(3), 267-291. https://doi. org/10.1007/s11251-016-9371-3

Gasong, D. (2018). Belajar dan
pembelajaran.
Deepublish.


Gunawan, G., Sahidu, H., Harjono, A., \& Suranti, N. M. Y. (2017). Efektivitas penerapan model project based learning berbantuan media virtual terhadap kreativitas fisika peserta didik. Jurnal Cakrawala Pendidikan, 36(2), 167-179. https://doi.org/10. 21831/cp.v36i2.13514

Hamalik, O. (2003). Proses belajar mengajar. Jakarta: Bumi Aksara.

Honomichl, R. D., \& Chen, Z. (2012). The role of guidance in children's discovery learning. Wiley Interdisciplinary Reviews: Cognitive Science, 3(6), 615-622. https://doi.org/10.1002/ WCS.1199

Hu, R., Wu, Y.-Y., \& Shieh, C.-J. (2016). Effects of virtual reality integrated creative thinking instruction on students' creative thinking abilities. EURASIA Journal of Mathematics, Science and Technology Education, 12(3), 477486. https://doi.org/10.12973/ eurasia.2016.1226a

Jihad, A., \& Haris, A. (2012). Evaluasi pembelajaran. Yogyakarta: Multi Presindo.

Kertamuda, F. (2008). Pengaruh motivasi belajar terhadap prestasi belajar. Jurnal Psikologi, 21(1), 27.

Kirschner, P. A., Sweller, J., \& Clark, R. E. (2006). Why minimal guidance during instruction does not work: An analysis of the failure of constructivist, discovery, problembased, experiential, and inquirybased teaching. Educational Psychologist, 41(2), 75-86. https://doi.org/10.1207/s15326985 ep4102_1

Kypuros, J. A., Tarawneh, C., Vasquez, H., Knecht, M., \& Wrinkle, R. (2012). Lessons learned implementing and optimizing guided discovery modules. 2012 Frontiers in Education Conference Proceedings, 1-6. https://doi.org/10.1109/FIE. 2012.6462463

Lazonder, A. W., \& Harmsen, R. (2016). Metaanalysis of inquiry-based learning. Review of Educational Research, 86(3), 681-718. https://doi.org/ 10.3102/0034654315627366

Loes, C. N., \& Pascarella, E. T. (2017). Collaborative learning and critical thinking: Testing the link. The Journal of Higher Education, 88(5),
726-753. https://doi.org/10.1080/ 00221546.2017 .1291257

Mirasi, W., Osodo, J., \& Kibirige, I. (2013). Comparing guided discovery and exposition-with-interaction methods in teaching biology in secondary schools. Mediterranean Journal of Social Sciences, 4(14), 81-87. https://doi.org/10.5901/mjss.2013. v4n14p81

Mulyasa, E. (2002). Manajemen berbasis sekolah, konsep strategi dan implementasi. Jakarta: Remaja Rosdakarya.

Nasution, S. (2000). Berbagai pendekatan dalam proses belajar dan mengajar. Jakarta: Bina Aksara.

Nchunga, A., \& Kira, E. (2016). Inclusion of real life materials in teaching physics concepts: Students' experiences and perceptions. International Journal of English and Education, 5(1), 1-14. Retrieved from http://www.suaire.suanet.ac.tz:808 0/xmlui/handle/123456789/2434

Sapriati, A. (2009). Pembelajaran IPA di SD. Jakarta: Universitas Terbuka.

Swaak, J., De Jong, T., \& Van Joolingen, W. R. (2004). The effects of discovery learning and expository instruction on the acquisition of definitional and intuitive knowledge. Journal of Computer Assisted Learning, 20(4), 225-234. https://doi.org/10.1111/ j.1365-2729.2004.00092.x

Widhiyantoro, T., Indrowati, M., \& Probosari, R. M. (2012). The effectiveness of guided discovery method application toward creative thingking skill at the tenth grade students of SMA N 1 Teras Boyolali in the academic year 2011/2012. Jurnal Pendidikan Biologi, 4(3), 8999. Retrieved from https://jurnal. uns.ac.id/bio/article/view/5596

Wilke, R. R., \& Straits, W. J. (2001). The effects of discovery learning in a lower-division biology course. Advances in Physiology Education, 25(2), 62-69. https://doi.org/10. 1152/advances.2001.25.2.62

Yamin, M. (2007). Kiat membelajarkan siswa. Jakarta: Gaung Persada Press.

Yuliani, K., \& Saragih, S. (2015). The development of learning devices based guided discovery model to 
improve understanding concept and critical thinking mathematically ability of students at islamic junior high school of Medan. Journal of Education and Practice, 6(24), 116-
128. Retrieved from https://files. eric.ed.gov/fulltext/EJ1078880.pdf 